\title{
Research on Changes of Small- and Medium-sized Sized Enterprise Culture
}

$$
\text { Zhang Dan 1, a , Lu Qing Qing }{ }^{2, b}
$$

\author{
${ }^{1}$ Business school of Xi'an innovation college of Yan`an university / School of Economics and \\ Management, Xi'an University of Arts and Science, Shaanxi, Xi'an, China \\ ${ }^{2}$ Business school of Xi an innovation college of Yan`an university, Shaanxi, Xi'an, China \\ adanzhang1969@126.com, b2731566413 @qq.com
}

\begin{abstract}
Keywords: small and medium-sized enterprises (SMEs), corporate culture, malignant tumor, transformation
\end{abstract}

\begin{abstract}
Most SMEs grew up under certain historical conditions. The SME culture spontaneously formed along with this particular historical condition is not fit for the requirements of the current "rule of culture" era any more, and it even becomes a cultural "malignant tumor" that hinders the further development of enterprises. Removing these "malignant tumors", carrying out cultural changes in SMEs, and gradually building a modern corporate culture that adapts to the development of the market economy is the key and symbol of the maturity of SMEs.
\end{abstract}

\section{Introduction}

In the face of drastic changes in the domestic and international market environment, and the fierce market competition, and being enslaved to the rule of "survival of the fittest", a large number of SMEs in China were eliminated as they cannot be successfully transformed or cannot adapt to the environment dynamically. "Be rash and bustling for a while, each leads the trend for three or two years" seems to have become a curse that many SMEs in China cannot get rid of. Surely there are many reasons could be found, but the most intrinsic, deepest, and most essential reason is supposed to be the problem of corporate culture. As the saying goes, "Sales brings one or two years' flourishing business, technology creates prosperity of three to five years, but the enduring prosperity depends on culture." Corporate culture is the internal basis of the survival and development of enterprises. Enterprises without culture do not exist. Those enterprises that lack excellent and strong cultural support are not competitive, and they are unlikely to prosper.

\section{SMEs must build a strong corporate culture}

The modern times is beyond the so-called "man rule" era of "experience management" and the "rule of law" era of "scientific management", but has entered the "rule of culture" era of "cultural management". The modern market and market competition have become mature and standardized, and far from the environment in the early days of the market economy that most SMEs in China are familiar with can compare with. Mature markets and standardized market competition are constructed on the basis of mature and excellent market culture essentially. To survive in such an era, and to compete in such a market, whether it is a newly established SME, or the SMEs that were born at the beginning period of China's market economy, they must adapt to the requirements of the times and the changes in the environment, and carefully construct appropriate, unique and excellent corporate culture. Only in this way can they strive for a place to live and a space for development. You can never neglect or give up the "lifeblood for enterprises' survival and development" with the excuse of small business. In fact, cultural competition is the strategic commanding height of today's corporate competition. Cultural prevails is the magic weapon for modern enterprises.

\section{A cultural "malignant tumor" that hinders the development of SMEs}

For many SMEs in China, to build a strong corporate culture, they must first fully recognize and resolutely eradicate the cultural "malignant tumor" that hinders the further development of 
enterprises. They should analyze the misunderstandings of SMEs in the corporate culture during past entrepreneurial process. We believe that the following five aspects have become the cultural "malignant tumors" that must be eradicated first.

\subsection{The corporate culture of "one person rules"}

At the beginning of the business, some SMEs mainly adopted the "workshop" business pattern and paid attention to the concept of "blood is thicker than water". They think that "their relatives are reliable", and this method of employment has become a fixed pattern, which makes the phenomenon of "cronyism" very common in companies. In this kind of kinship human resource system, the status of the business owner is supreme, and only one person has the final say, the enterprise management system is ineffective, the management is loose and casual, and there is no institutionalization or standardization at all. The level of management depends on the boss's personal talent and experience. Lack of collective wisdom, there is no effective management mechanism and team decision-making mechanism, the boss has the final say, decision-making is often lack of reason and constraints. The strategy of enterprise development is determined by relationship, the fate of enterprise is maintained by kinship, and the existence and development of enterprise are buried with deep hidden dangers and huge risks.

\subsection{The corporate culture of "captain's call"}

The founders of most SMEs have a certain adventurous spirit. Their cultural quality is not necessarily high. They fight in the business world with a group of faithful pals with brute forces regardless of risks and with the established interpersonal relationships. They even frantically speculate and finance. Along the years, they have developed a habit of ignoring the reality, being blindly greedy, doing things by experience, and making controversial decisions. When other companies have taken the road of expanding and diversifying, they imitate without thinking and could not wait to expand the scale and march into new markets. The company is turned into a "blowing balloon" that may explode at any time. Always holding the "car to the mountain there must be a way" by luck, then their own enterprises, to outsiders do not trust habits. Although there are some external managers in some enterprises, they still like to be bossy, which makes a large number of middle and lower managers have the power and authority, and forms the management style that functional departments dare not make decisions on matters of great size and details and wait for the boss's instructions.

\subsection{Corporate culture of star effect}

The SMEs are small in scale, weak in strength, and lack of technology developing capabilities. However, SMEs have a killer trick, which is to make use of star effect to advertise, and to obtain market attention and brand identity. It is an effective means to quickly increase brand awareness, but using the image spokesperson to engage in marketing and form a corporate culture is just a part, not all. Advertising, brand building, market expansion and product development, capital operation interact with each other, and advertisement will lead the brand to death.

\subsection{Corporate culture of fighting alone}

All the founders of SMEs have the ideas like fighting alone, stragglers, better be the head of an ass than the tail of a horse, and never be other people's "processing workshop", etc. Their corporate culture advocates the spirit of fighting alone, and ignores cooperation. Only by breaking the mentality of fighting alone in the corporate culture, establishing new thinking, new ideas, and new culture of collaborative competition, that enterprises could get out of the predicament and be successful in the future.

\subsection{Short-sighted and extreme corporate culture.}

Small and medium-sized enterprises put their immediate economic interests first, while ignoring quality and service. Most of the small and medium-sized enterprises have the idea of "the boat is easy to turn around". They imitate what products are popular in the market and keep up with the hot 
spots in the market. However, due to the weak technical strength of small and medium-sized enterprises, they only focus on quantity and speed in the process of imitating manufacturing, but ignore the product quality and after-sales service, or even substitute inferior products for inferior ones, fake and shoddy ones, and exchange one shot for another. There is no requirement for rapid development and strategic planning, and they can only make money. Not only can the enterprise itself not develop and grow for a long time, but also it loses credibility, has no personality, and can't find a way that is really suitable for its long-term development.

\section{The basic direction of the cultural reform of SMEs}

Corporate culture is something that has generality. It needs to be cultivated from a small age, and be perfected by accumulation gradually. Regarding the "malignant tumors" that hinder the development of SMEs, it is necessary to build its culture and implement the following changes:

\subsection{Constructing the rational corporate culture}

The irrational blood bond and emotion bond belong to the economic awareness of small farmers, which is incompatible with the modern market economy. An enterprise is an economic entity, and its operation must conform to the operating laws of the market economy. As a community, an enterprise is essentially a rational organism. Therefore, people must make up their minds to get rid of the bond of blood and emotion, and build a rational culture based on business.

\subsection{Mainstream of corporate culture construction}

First of all, the entrepreneurs of SMEs should abide by the management philosophy of humanism, and should fully realize that beyond company's product competition, technological competition, and capital competition, it is the talent competition that really matters essentially. Secondly, SMEs should spend great efforts to create a cultural atmosphere of "appointing people by abilities" within the enterprise, and have respect, trust, care, understanding, and motivating employees to have a high sense of responsibility and strong enthusiasm for achieving corporate goals as the basic content of "people-oriented" idea. Thirdly, SMEs should not only broaden their horizons, but also introduce foreign talents to manage companies. Compete reasonably, learn from each other's strengths, and form human resources and advantages. They must boldly delegate their power to the talents so that they can make decisions scientifically and rationally according to the competitive trend of the market. Lastly, what's more important is that the leaders of SMEs play a pivotal role in determining the direction of business development and business policies. The development strategy and business policy of the enterprise itself are the core carriers of corporate culture, so the helmsman also plays the role of a cultural leader in forming the company's practical, scientific, and talent-oriented management style and value. Being a good corporate culture leader, playing a good cultural axis role, and leading employees to build a strong corporate culture, these helmsmen have great responsibilities and should have higher requirements for themselves.

\subsection{Building a "honest" corporate culture}

Honesty is the foundation of a company's long-term survival and development. Only by adhering to the concept of honesty in business activities can an enterprise win the trust and support of its customers, and achieve a good relationship, keep its old customers, and attract new customers, keep original market and create new markets. Thus the company could develop sustainably with high profitability. It can be seen that only the "honesty-based" corporate culture can truly be responsible to customers and create a strong magnetic field that attracts customers, and maintain long-term vitality in the fierce market competition.

\subsection{Building a corporate brand culture}

In order to improve their popularity, many SMEs have spared no expense in advertising and vying for "bidder king" while the company itself does not have the financial strength to support it. Therefore, there comes the saying that "the brand will be advertised to die". In fact, the market 
significance of the brand lies in the specific culture attached to the brand, like the so-called "it is culture behind the famous brand". Brand is the carrier of culture. Culture is the essence of the enterprise that condensed on the brand. It is also the concept and will, and behavior norm, group style that penetrate into the whole process and all sides of the company's operation.

\subsection{Building a "learning" corporate culture}

The "learning" corporate culture has a remarkable role and significance. Its essence is: on one hand, learning is to improve the cultural knowledge of employees, so that employees can better accomplish their tasks. It brings the realization of employees' personal values and work achievements together, so that employees can gain the meaning of life at work. On the other hand, in order to ensure the survival of enterprises, they ought to study the current situation and development trends, so that enterprises have the ability to improve continuously, raise the competitiveness of enterprise organizations Learning is to produce a new concept of continuous innovation and improvement, so that enterprises can integrate resources constantly and meet new challenges.

\section{Conclusion}

In short, excellent corporate culture is the soul and DNA of the enterprise. It determines the characteristics of the enterprise, and is the source of vitality of the century-old enterprise, and is the turbocharged engine of all innovative activities of the enterprise. Cultural management is the highest level of business management, and cultural competition is the ultimate competition of enterprises. Of course, corporate culture is also an open system. It needs to be inclusive, constantly absorbing all the outstanding external cultures, advancing with the times, and constantly innovating, so that it can provide more, better and special vitality for the cultivation of the core competitiveness of enterprises. We must cultivate and build our own unique and excellent corporate culture.

\section{References}

[1] Qian Gaoyuan. Corporate Culture [M]. Beijing. China Textile Press, 2002.

[2] Wei Jie. Corporate Culture Modeling: The Ivy of Enterprise Life [M]. Beijing. China Development Press, 2002.

[3] Guo Jianbin. Analysis of the relationship between corporate culture construction, enterprise management and economic benefits [J]. China Business Theory, 2019, 19, 122

[4] Han Lei. Strengthening the Research of Enterprise Culture Construction [J]. Modern Marketing (Business Edition), 2019, 10 